\title{
Rancangan dan Evaluasi Sistem Informasi Inventori APD untuk Covid-19 dengan Metode PIECES
}

\author{
Jefril Rahmadoni ${ }^{\# 1}$, Adi Arga Arifnur ${ }^{\# 2}$, Ricky Akbar ${ }^{\# 3}$

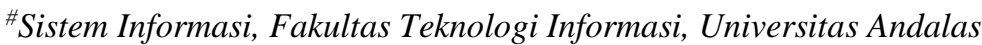 \\ Limau Manis, Kec. Pauh, Kota Padang, Sumatera Barat 25175 \\ ${ }^{1}$ jefrilrahmadonieit.unand.ac.id \\ 2adiargaarifnureit.unand.ac.id \\ ${ }^{3}$ rickyakbardit.unand.ac.id
}

\begin{abstract}
Abstrak-Salah satu bagian yang begitu penting dalam menanggulangi Covid-19 adalah Alat pelindung diri (APD). Setiap tenaga kesehatan yang berhadapan dengan pasien Covid-19 harus menggunakan APD dan setiap fasilitas kesehatan yang ada di kota Padang harus memiliki stok APD agar selalu ada saat dibutuhkan. Namun kondisi APD di setiap fasilitas kesehatan yang terdapat di kota Padang tidak di rekap secara komputerisasi, petugas harus memeriksa ketersedian APD di gudang setiap saat. Tujuannya penelitian ini adalah agar setiap fasilitas kesehatan yang ada di kota Padang mengetahui ketersediaan APD setiap saat melalui sistem informasi yang berbasis web tanpa harus memeriksa di gudang agar tidak ada lagi kematian dari tenaga kesehatan akibat menangani pasien yang positif Covid-19 tanpa menggunakan APD. Dalam perancangan sistem digunakan metode waterfall. Sedangkan dalam evaluasi sistem yang telah diimplementasikan memanfaatkan metode PIECES (Performance, Information/Data, Economic, Control/Security, Efficiency, Service). Berdasarkan hasil dari setiap tahapan metode waterfall yaitu tahapan analisis, perancangan, pengkodean, dan implementasi, maka dapat ditarik sebuah kesimpulan bahwa perancangan aplikasi sistem informasi inventari APD di DKK Padang telah berhasil dibangun sesuai dengan kebutuhan. Evaluasi yang dilakukan terhadap sistem yang telah dirancang dan diimplentasikan menunjukkan bahwa nilai mean adalah sebesar 3,66 dengan kategori baik.
\end{abstract}

Kata kunci- Covid-19, Sistem Informasi, Inventori, Alat Pelindung Diri, Evaluasi Sisem, PIECES

\section{PENDAhUluan}

Perkembangan teknologi yang begitu pesat membuat keberadaan teknologi saat ini sangat diperlukan dalam mengolah data. Tanpa teknologi data masih bisa diolah untuk dijadikan sebuah informasi, namun membutuhkan waktu yang cukup lama dan informasi yang disajikan terkadang terdapat kesalahan. Segala macam kegiatan sangat membutuhkan bantuan teknologi informasi untuk memudahkan pekerjaan [1]. Dengan adanya teknologi, penyediaan informasi dari data yang diolah bisa memakan waktu yang lebih singkat dan kesalahan akan bisa di minimalisir.

Salah satu peranan teknologi saat ini adalah dalam penanggulanagan masalah Corona Virus Desease 2019 (Covid-19) baik dunia secara umum, maupun Indonesia secara khusus. Pengolahan data Covid-19 menjadi sebuah informasi sangat dibutuhkan agar pengguna informasi tersebut dapat mengetahui penyebaran Covid-19, tapi tidak hanya itu namun banyak sekali informasi yang berkenaan dengan Covid-19 yang bisa didapati dengan menggunakan teknologi.

Penyebaran Covid-19 begitu sangat cepat dan sudah menjadi pandemi global sejak ditetapkan oleh WHO pada bulan Maret 2020. Penggunaan Alat Pelindung Diri (APD) merupakan salah satu pencegahan COVID-19 yang efektif [2].

Indonesia merupakan salah satu negara yang penyebaran Covid-19 meningkat secara signifikan, tidak terkecuali provinsi Sumatera Barat dengan ibukota Padang. Jumlah kematian akibat Covid-19 di provinsi Sumatera Barat per tanggal 2 Mei 2020 adalah sebanyak 15 orang dengan total positif sebanyak 182 orang. Jumlah orang yang terkonfirmasi positif di Sumatera Barat terus meningkat dan yang positif tidak hanya masyarakat biasa melainkan juga tenaga kesehatan yang sangat rentan ditulari oleh pasien yang positif Covid-19.

Petugas kesehatan sebagai garda terdepan layanan kesehatan [3]. Tenaga Kesehatan merupakan garda terakhir dalam menjalankan untuk menangani Covid-19 ini baik pasien yang ODP (orang dalam pantauan), PDP (pasien dalam pengawasan), OTG (orang tanpa gejala), dan terlebih pasien yang terkonfirmasi positif harus menggunakan APD. Menjaga penyedia layanan kesehatan agar tetap sehat dan tersedia bekerja selama pandemi ini sangat penting [4]. Dalam keamanan kerja analisis, setiap langkah dasar pekerjaan harus ditaati sehingga potensi bahaya diidentifikasi, rekomendasi dicari untuk cara yang paling aman dalam melakukan tugas [5]. 
Saat ini setiap fasilitas kesehatan harus memiliki APD yang lengkap dalam upaya menanggulangi Covid-19. Penggunaan APD yang meluas saat ini tidak sebatas kontak dengan pasien COVID-19 di unit khusus dan terisolasi, melainkan dalam berbagai konteks, dan di masyarakat umum [6]. Dalam buku Pedoman Umum Menghadapi Pandemi Covid-19 bagi Daerah; Pencegahan, Pengendalian, Diagnosa dan Manajemen yang disusun dan dikompilasi oleh tim kerja Kementrian Dalam Negeri untuk dukung Gugus Tugas Covid-19 diatur bagaimana cara pemakaian dan pelapasan APD. Namun tidak ada sebuah peraturan baku yang mengatur jumlah ketersidaan APD di masingmasing fasilitas kesehatan. Pemerintah pusat dan daerah menyerahkan ke masing-masing fasilitas kesehatan untuk jumlah ketersediaan APD.

Salah satu persyaratan paling penting dalam memerangi Covid-19 adalah APD. Penggunaan APD merupakan salah satu Pengendalian Infeksi dan Infeksi Program pencegahan termasuk dalam tindakan pencegahan isolasi disusun oleh Pusat Pengendalian dan Pencegahan Penyakit (CDC) dan tindakan pengendalian infeksi yang paling penting adalah tangan kebersihan [7].

Setiap tenaga kesehatan yang berhadapan dengan pasien Covid-19 harus menggunakan APD dan setiap fasilitas kesehatan yang ada di kota Padang harus memiliki stok APD agar selalu ada saat dibutuhkan. Namun, keadaan APD di masing-masing fasilitas kesehatan Padang belum terkomputerisasi, petugas harus memeriksa ketersedian APD di gudang setiap saat. Hal ini menyebabkan tidak terkontrolnya persediaan APD dan terkadang kehabisan stok ketika saat dibutuhkan.

Di sisi lain, dengan kebutuhan yang sangat luas akan alat pelindung diri, maka penting untuk membangun sistem informasi manajemen alat [8]. Sistem informasi yang terkomputerisasi dapat digunakan untuk menyelesaikan masalah yang muncul pada sistem yang sedang berjalan dengan cepat. Sehingga penyimpanan dan pengolahan data yang sebelumnya manual (di lemari arsip) dapat dimutakhirkan menjadi sistem informasi yang terhubung dengan database [9]. Pengembangan sistem informasi yang bertujuan untuk memperbaiki sistem atau perangkat lunak yang telah dibuat sebelumnya dan tidak dapat diselesaikan dalam satu atau dua hari tetapi harus dilakukan dengan cermat dan terencana [10]. Sementara Nusa [11] juga menjelaskan bahwa Sistem informasi dapat membantu pengendalian proses bisnis yang berdampak pada peningkatan pengendalian internal, serta memberikan solusi pelaksanaan audit. Strategi sistem informasi didefinisikan sebagai penggunaan teknologi informasi untuk mendukung atau melaksanakan rencana persaingan lembaga, dan penerapannya dapat meningkatkan daya saing [12].

Secara umum inventori tidak hanya untuk memenuhi permintaan produksi normal, tetapi juga untuk mengontrol persediaan, untuk memastikan operasi normal dan menghindari mengambil banyak likuiditas [13]. Inventori adalah proses yang efisien mengawasi aliran konstan unit masuk dan keluar dari sebuah stok barang yang ada [14].
Penelitian sebelumnya tentang sistem informasi persediaan meliputi penelitian implementasi dan perancangan sistem informasi manajemen persediaan yang menyediakan informasi stok barang dan laporan semesteran penerimaan dan pengeluaran barang secara realtime, sehingga proses pelaporan dan pengendalian informasi stok dapat dilakukan dengan baik. Diantaranya penelitian yang dilakukan oleh Bari dan Kasmawi [15]; Rosidin dan Lubis [16]; Veza [17]; Ripanti [18], dan Rumetna, dkk [19]. Sedangkan pada penelitian ini selain memberikan informasi stok barang secara real time, terdapat alur komunikasi antar user pada aplikasi yang terintegrasi dengan stok barang. Kemudian penelitian ini juga terdapat evaluasi terhadap sistem yang telah diimplementasikan dengan menyebarkan kuesioner kepada seluruh user yang menggunakan aplikasi ini.

\section{Metode Penelitian}

Metode waterfall digunakan untuk membangun aplikasi dalam penelitian ini. Waterfall adalah paradigma tradisional dan metodis yang digunakan sebagai pedoman untuk membuat proyek yang inovatif dan sulit [20]. Teknik waterfall adalah pendekatan pengembangan perangkat lunak sekuensial dimana kemajuan dianggap terus mengalir ke bawah karena sistem dikembangkan melalui beberapa tahap seperti analisis, desain, pengkodean, dan pengujian [21]; [22]. Selanjutnya, model ini terdiri dari pengulangan dalam bentuk fase sistem SDLC [23]. Strategi ini menggunakan pendekatan metodis dan sekuensial. Metode air terjun dinamai demikian karena tahapan yang dilalui harus menunggu tahapan sebelumnya diselesaikan sebelum melanjutkan. Penelitian dengan metode Warerfall juga digunakan sebelumnya dalam penelitian yang dilakukan oleh Lubis [24] dan juga Puspitasari [25]. Dengan penggunaan metode Waterfall, waktu dapat didistribusikan secara optimal karena setiap fase memiliki alokasi waktu yang ditentukan, tetapi jika satu pekerjaan terlambat, semua tugas akan terlambat [26]. Gambar 1 menggambarkan metode air terjun

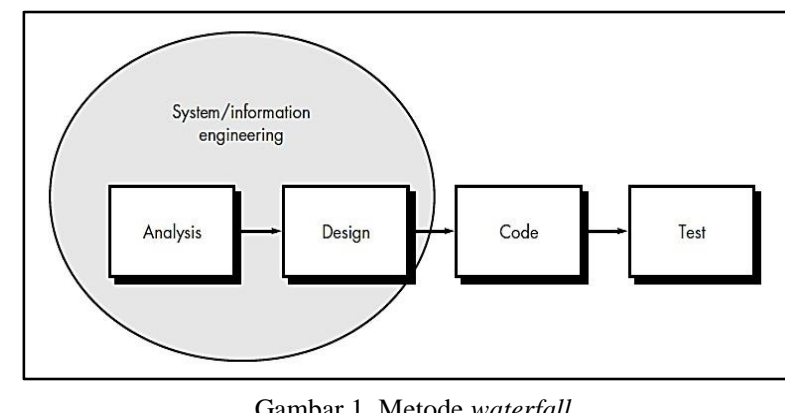

Flowchart penelitian ini menjelaskan prosedur yang terlibat dalam mendesain aplikasi seperti yang terlihat pada gambar 2 berikut: 


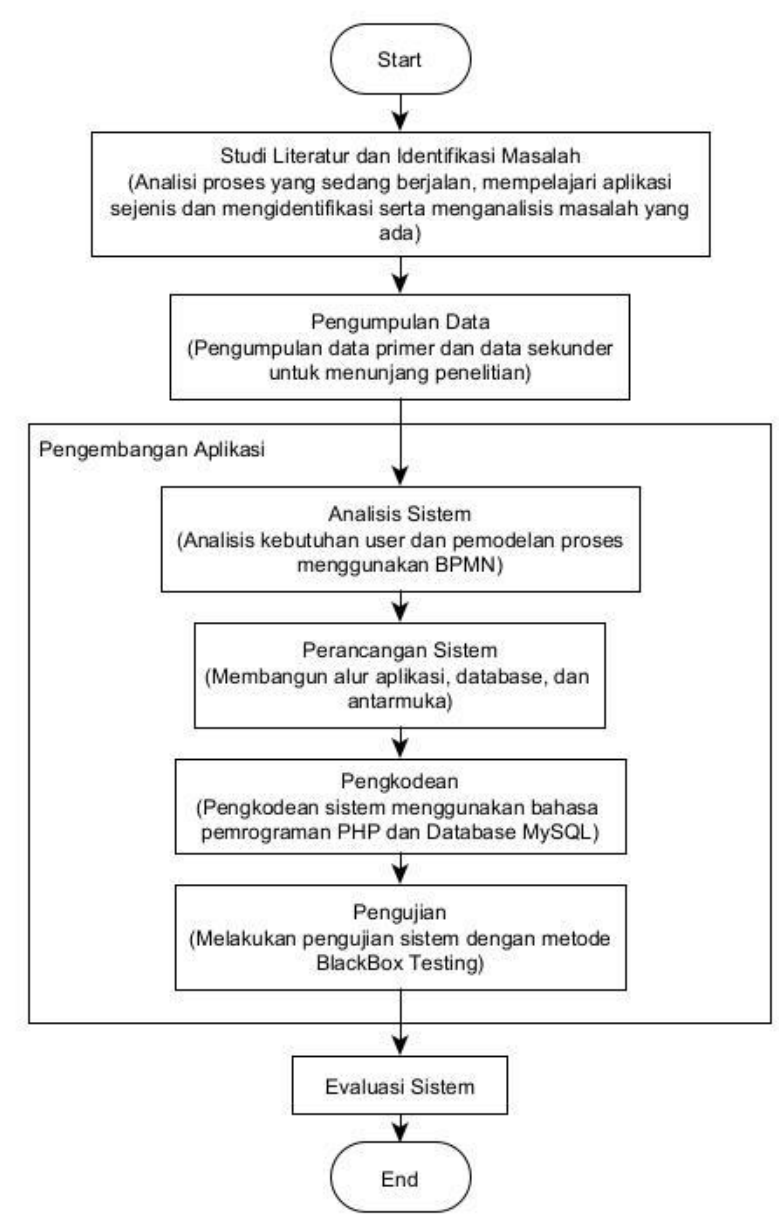

Gambar 2. Flowchart penelitian

Terdapat beberapa tahapan pada flowchart penelitian ini, Diawali dengan tinjauan pustaka yang relevan dengan rumusan masalah, pengumpulan data dilakukan melalui observasi, wawancara, dan pengumpulan dokumendokumen yang berkaitan dengan penunjang penelitian. Kemudian dilanjutkan ke tahap pengembangan aplikasi, diawali dengan analisis kebutuhan dan model proses bisnis sesuai dengan informasi yang sudah dihimpun sebelumnya. Kemudian dilanjutkan dengan tahap perancangan, tahap ini dilakukan dengan merancang kebutuhan pada aplikasi termasuk model tampilan aplikasi berdasarkan hasil analisis sistem yang akan dibangun. Tahapan selanjutnya adalah pengkodean, implementasi hasil desain sistem ke dalam bahasa pemrograman. Tahap terakhir dalam tahap pengembangan aplikasi adalah pengujian, dimana aplikasi diuji untuk melihat apakah sudah berjalan dengan baik dan sesuai dengan fungsionalitas yang direncanakan. Selanjutnya adalah evaluasi sistem dengan menggunakan metode PIECES.

Metode evaluasi PIECES adalah kerangka kerja untuk mengkategorikan masalah, peluang, dan arah dalam lingkup analisis dan desain sistem [27]. Pada metode PIECES ini terdiri atas kinerja sistem (performance), informasi yang disajikan (information/data), ekonomis sistem (economic), pengendalian dan keamanan sistem (control/security), praktis (efficiency), dan fasilitas (service).

Masing-masing kategori dari metode PIECES ini memiliki beberapa indikator, yaitu: 1) performance (throughput, response time, audibility, kelaziman komunikasi, kelengkapan, konsistensi, dan toleransi kesalah); 2) Information/Data (accuracy, relevansi informasi, menyajikan informasi, dan fleksibilitas data); 3) Economic (reusability, dan sumber daya); 4) Control (integritas, dan kemanan); 5) Efficiency (usability, dan maintainability); 6) Service (akurasi, reliability, dan kesederhanaan).

Populasi pada penelitian ini dalam melakukan evaluasi sistem informasi ini terdiri dari seluruh pengguna pada aplikasi ini sejumlah 25 orang, yaitu 2 orang dari pengguna Dinas Kesehatan Kota (DKK) Padang dan 23 orang dari pengguna masing-masing puskesmas yang terdapat di kota Padang. Dikarenakan jumlah populasinya ada 25 orang, maka yang menjadi sampel ada total populasi yang ada, yaitu sebanyak 25 orang.

Indikator dan variabel dalam penelitian ini yang digunakan sebagai evaluasi sistem dapat dirincikan pada tabel dibawah ini:

TABEL I

INDIKATOR DAN VARIABEL

\begin{tabular}{|c|c|c|}
\hline Indikator & $\begin{array}{c}\text { Defenisi } \\
\text { Operasional }\end{array}$ & Kategori \\
\hline \multicolumn{3}{|l|}{ Performance } \\
\hline Throughput & $\begin{array}{l}\text { Secara umum, } \\
\text { sistem } \\
\text { menghasilkan } \\
\text { output }\end{array}$ & $\begin{array}{ll}\text { 1. } & \text { Sedikit sekali } \\
\text { 2. } & \text { Sedikit } \\
\text { 3. } & \text { Lumayan banyak } \\
\text { 4. } & \text { Banyak } \\
\text { 5. } & \text { Sangat banyak }\end{array}$ \\
\hline Response time & $\begin{array}{l}\text { Sistem melakukan } \\
\text { proses kerja secara } \\
\text { bertahap }\end{array}$ & $\begin{array}{ll}\text { 1. } & \text { Lambat sekali } \\
\text { 2. } & \text { Lambat } \\
\text { 3. } & \text { Lumayan cepat } \\
\text { 4. } & \text { Cepat } \\
\text { 5. } & \text { Cepat sekali }\end{array}$ \\
\hline Audibility & $\begin{array}{l}\text { Sesuai dengan } \\
\text { standar yang } \\
\text { ditetapkan dengan } \\
\text { fungsi kerja sistem }\end{array}$ & $\begin{array}{ll}\text { 1. } & \text { Tidak sesuai sekali } \\
\text { 2. } & \text { Tidak sesuai } \\
\text { 3. } & \text { Lumayan sesuai } \\
\text { 4. } & \text { Sesuai } \\
\text { 5. } & \text { Sesuai sekali }\end{array}$ \\
\hline $\begin{array}{l}\text { Kelaziman } \\
\text { Komunikasi }\end{array}$ & $\begin{array}{l}\text { Pengguna mudah } \\
\text { memahami } \\
\text { antarmuka sistem }\end{array}$ & $\begin{array}{ll}\text { 1. } & \text { Sulit sekali } \\
& \text { dipahami } \\
\text { 2. } & \text { Sulit dipahami } \\
\text { 3. } & \text { Lumayan mudah } \\
\text { dipahami } \\
\text { 4. } \\
\text { 5. } & \text { Mudah dipahami } \\
& \text { dipahami }\end{array}$ \\
\hline Kelengkapan & $\begin{array}{l}\text { Dalam hal desain } \\
\text { dan dokumentasi, } \\
\text { digunakan sistem } \\
\text { yang tidak lengkap. }\end{array}$ & $\begin{array}{ll}\text { 1. } & \text { Tidak lengkap } \\
& \text { sekali } \\
\text { 2. } & \text { Tidak lengkap } \\
\text { 3. } & \text { Lumayan lengkap } \\
\text { 4. } & \text { Lengkap } \\
\text { 5. } & \text { Lengkap sekali }\end{array}$ \\
\hline $\begin{array}{l}\text { Toleransi } \\
\text { Kesalahan }\end{array}$ & $\begin{array}{l}\text { Saat membuat } \\
\text { beberapa kesalahan, } \\
\text { sistem akan crash } \\
\text { sebentar }\end{array}$ & $\begin{array}{ll}\text { 1. } & \text { Banyak sekali } \\
\text { 2. } & \text { Banyak } \\
\text { 3. } & \text { Lumayan sedikit } \\
\text { 4. } & \text { Sedikit } \\
\text { 5. } & \text { Sedikit sekali }\end{array}$ \\
\hline
\end{tabular}




\begin{tabular}{|c|c|c|}
\hline Indikator & $\begin{array}{c}\text { Defenisi } \\
\text { Operasional }\end{array}$ & Kategori \\
\hline \multicolumn{3}{|c|}{ Information/Data } \\
\hline Akurasi & $\begin{array}{l}\text { Proses perhitungan } \\
\text { dari sistem }\end{array}$ & $\begin{array}{l}\text { 1. Tidak teliti sekali } \\
\text { 2. Tidak teliti } \\
\text { 3. Lumayan teliti } \\
\text { 4. Teliti } \\
\text { 5. Teliti sekali }\end{array}$ \\
\hline $\begin{array}{l}\text { Relevansi } \\
\text { Informasi }\end{array}$ & $\begin{array}{l}\text { Informasi yang } \\
\text { diperoleh sesuai } \\
\text { dengan kebutuhan } \\
\text { pengguna }\end{array}$ & $\begin{array}{ll}\text { 1. } & \text { Tidak sesuai sekali } \\
\text { 2. } & \text { Tidak sesuai } \\
\text { 3. } & \text { Lumayan sesuai } \\
\text { 4. } & \text { Sesuai } \\
\text { 5. } & \text { Sesuai sekali }\end{array}$ \\
\hline $\begin{array}{l}\text { Menyajikan } \\
\text { Informasi }\end{array}$ & $\begin{array}{l}\text { Informasi yang } \\
\text { ditampilkan tidak } \\
\text { sesuai dengan } \\
\text { kebutuhan } \\
\text { pengguna }\end{array}$ & $\begin{array}{ll}\text { 1. } & \text { Tidak sesuai sekali } \\
\text { 2. } & \text { Tidak sesuai } \\
\text { 3. } & \text { Lumayan sesuai } \\
\text { 4. } & \text { Sesuai } \\
\text { 5. } & \text { Sesuai sekali }\end{array}$ \\
\hline $\begin{array}{l}\text { Fleksibilitas } \\
\text { Data }\end{array}$ & $\begin{array}{l}\text { Akses dan/atau } \\
\text { penggunaan data } \\
\text { yang sederhana } \\
\text { hingga yang sulit }\end{array}$ & $\begin{array}{ll}\text { 1. } & \text { Sulit sekali } \\
\text { 2. } & \text { Tidak sulit } \\
\text { 3. } & \text { Lumayan mudah } \\
\text { 4. } & \text { Mudah } \\
\text { 5. } & \text { Mudah sekali } \\
\end{array}$ \\
\hline \multicolumn{3}{|l|}{ Economic } \\
\hline Reusability & $\begin{array}{l}\text { Banyak program } \\
\text { memiliki potensi } \\
\text { untuk digunakan } \\
\text { kembali di aplikasi } \\
\text { lain. }\end{array}$ & $\begin{array}{ll}\text { 1. } & \text { Sedikit sekali } \\
\text { 2. } & \text { Sedikit } \\
\text { 3. } & \text { Lumayan banyak } \\
\text { 4. } & \text { Banyak } \\
\text { 5. } & \text { Banyak sekali }\end{array}$ \\
\hline Sumber Daya & $\begin{array}{l}\text { Sistem dijalankan } \\
\text { oleh sejumlah kecil } \\
\text { pengguna }\end{array}$ & $\begin{array}{ll}\text { 1. } & \text { Banyak sekali } \\
\text { 2. } & \text { Banyak } \\
\text { 3. } & \text { Lumayan sedikit } \\
\text { 4. } & \text { Sedikit } \\
\text { 5. } & \text { Sedikit sekali }\end{array}$ \\
\hline \multicolumn{3}{|c|}{ Control/Security } \\
\hline Integritas & $\begin{array}{l}\text { Sistem } \\
\text { memberlakukan } \\
\text { pembatasan yang } \\
\text { sesuai pada } \\
\text { operator untuk } \\
\text { program tertentu }\end{array}$ & $\begin{array}{ll}\text { 1. } & \text { Tidak sesuai sekali } \\
\text { 2. } & \text { Tidak sesuai } \\
\text { 3. } & \text { Lumayan sesuai } \\
\text { 4. } & \text { Sesuai } \\
\text { 5. } & \text { Sesuai sekali }\end{array}$ \\
\hline Keamanan & $\begin{array}{l}\text { Keamanan data di } \\
\text { jamin oleh sistem }\end{array}$ & $\begin{array}{ll}\text { 1. } & \text { Tidak aman sekali } \\
\text { 2. Tidak aman } \\
\text { 3. Lumayan aman } \\
\text { 4. Aman } \\
\text { 5. Aman sekali } \\
\end{array}$ \\
\hline \multicolumn{3}{|l|}{ Efficiency } \\
\hline Usability & $\begin{array}{l}\text { Upaya pengguna } \\
\text { yang diperlukan } \\
\text { untuk mempelajari } \\
\text { dan } \\
\text { mengoperasikan } \\
\text { sistem } \\
\end{array}$ & $\begin{array}{ll}\text { 1. } & \text { Sulit sekali } \\
\text { 2. } & \text { Sulit } \\
\text { 3. } & \text { Lumayan mudah } \\
\text { 4. } & \text { mudah } \\
\text { 5. } & \text { Mudah sekali }\end{array}$ \\
\hline Maintainability & $\begin{array}{l}\text { Pencarian dan } \\
\text { perbaikan } \\
\text { kesalahan sistem } \\
\text { yang mudah } \\
\text { digunakan } \\
\end{array}$ & $\begin{array}{ll}\text { 1. } & \text { Sulit sekali } \\
\text { 2. } & \text { Sulit } \\
\text { 3. } & \text { Lumayan mudah } \\
\text { 4. } & \text { Mudah } \\
\text { 5. } & \text { Mudah sekali } \\
\end{array}$ \\
\hline \multicolumn{3}{|l|}{ Service } \\
\hline Akurasi & $\begin{array}{l}\text { Proses kerja yang } \\
\text { dilakankan oleh } \\
\text { sistem }\end{array}$ & $\begin{array}{ll}\text { 1. } & \text { Tidak teliti sekali } \\
\text { 2. } & \text { Tidak teliti } \\
\text { 3. } & \text { Lumayan teliti } \\
\text { 4. } & \text { Teliti } \\
\text { 5. } & \text { Teliti sekali } \\
\end{array}$ \\
\hline Reability & $\begin{array}{l}\text { Dapat } \\
\text { mengandalkan } \\
\text { sistem untuk } \\
\text { menyelesaikan } \\
\text { pekerjaan yang } \\
\text { diminta } \\
\end{array}$ & $\begin{array}{l}\text { 1. } \text { Tidak dapat sekali } \\
\text { 2. Tidak dapat } \\
\text { 3. Lumayan dapat } \\
\text { 4. Dapat } \\
\text { 5. Dapat sekali }\end{array}$ \\
\hline
\end{tabular}

\begin{tabular}{|c|l|ll|}
\hline Indikator & \multicolumn{1}{|c|}{$\begin{array}{c}\text { Defenisi } \\
\text { Operasional }\end{array}$} & & Kategori \\
\hline Kesederhanaan & Sistemnya mudah & 1. & Sulit sekali \\
& dipahami pengguna & 2. & Sulit \\
& & 3. & Lumayan sulit \\
& & 4. & Mudah \\
& & 5. & Mudah sekali \\
\hline
\end{tabular}

\section{HASIL DAN PEMBAHASAN}

\section{A. Analisis Sistem}

1) Sistem Berjalan: Sistem yang saat ini beroperasi adalah sistem pengendalian stok APD di Dinas Kesehatan Kota Padang dan Puskesmas, serta arus permintaan barang dari Puskesmas ke DKK Padang. Model alur permintaan barang dan pengendalian stok barang dapat digambarkan dengan menggunakan tools BPMN, dijelaskan sebagai berikut:

\section{a. Model Bisnis Permintaan Barang}

Dalam proses pengendalian stok barang APD pada DKK Padang pasti ada proses permintaan barang dari puskesmas ke DKK Padang. Proses permintaan barang ini akan mempengaruhi stok yang ada pada DKK Padang dan puskesmas. Proses permintaan barang saat ini dilakukan oleh puskesmas adalah dengan cara telepon, SMS atau WA kepada pihak DKK Padang atau langsung datang ke DKK Padang, kemudian setelah itu baik DKK Padang melakukan update jumlah stok barang yang ada. Rekapan jumlah barang hanya dilakukan oleh DKK Padang dan ini tidak dilakukan oleh puskesmas. Sehingga DKK Padang tidak mengetahui berapa jumlah stok barang yang ada pada setiap puskesmas. Model bisnis permintaan barang yang saat ini sedang berjalan dapat dilihat pada gambar 3 .

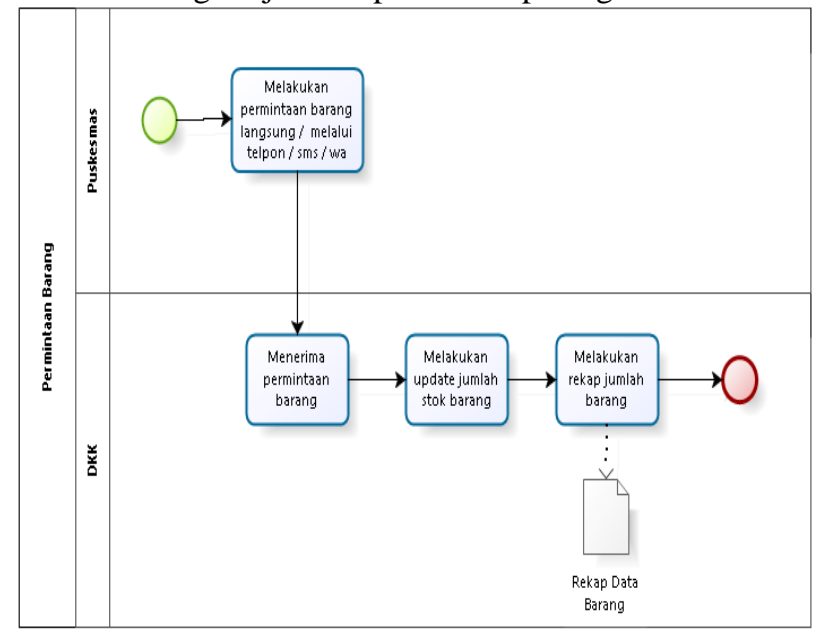

Gambar 3. Model bisnis permintaan barang yang sedang berjalan

\section{b. Model Bisnis Pengendalian Stok Barang}

Pengendalian stok barang APD yang dilakukan secara konvensional saat ini hanya dilakukan pada DKK Padang dan DKK Padang tidak mengetahui berapa jumlah stok barang yang ada di setiap puskesmas. Alur pengendalian stok barang APD berupa: 1) DKK Padang melakukan input data ke Microsoft Excel barang yang masuk yang disertakan dengan dari mana sumber barang dan tanggal 
masuk barang tersebut. Contoh: barang masuk berupa Termometer Gun sebanyak 10 pcs dari BPBD Kota Padang. Pada proses ini barang akan bertambah; 2) Barang akan berkurang jika ada permintaan dari puskesmas dengan cara input data ke Microsoft Excel yang disertakan dengan nama puskesmas yang melakukan permintaan; 3) Stok barang akan selalu di update setiap hari oleh petugas pada bagian Sumber Daya Kesehatan dan petugas tersebut juga harus melakukan pemeriksaan di gudang untuk menyesuaikan dengan laporan yang dibuat di Microsoft Excel.

Gambar 4 menggambarkan model bisnis pengendalian saham saat ini:

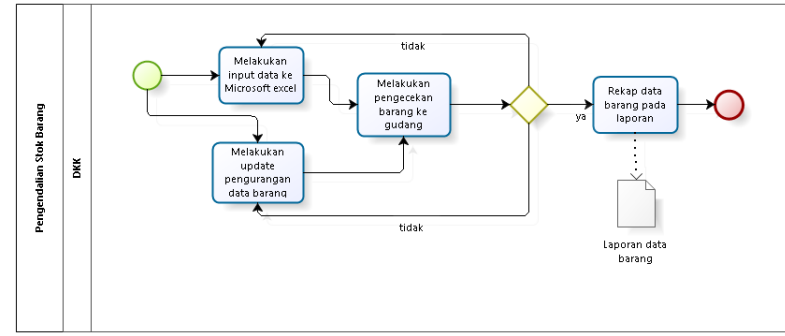

Gambar 4. Model bisnis pengendalian stok barang yang sedang berjalan

2) Sistem yang Diusulkan: Sistem yang ada saat ini kurang efektif, menurut observasi dan wawancara yang dilakukan di DKK Padang, khususnya di bagian Sumber Daya Kesehatan yang mengontrol stok APD. Pengendalian stok APD membutuhkan waktu lama dan banyak tenaga manusia, dan sering terjadi ketidaksesuaian antara stok barang di gudang dan data yang telah direkapitulasi di Microsoft Excel. Permintaan barang yang belum tersistem, terkadang setelah membaca WA atau SMS, user tidak langsung melakukan eksekusi terhadap permintaan sehingga pihak puskesmas harus menunggu lama dan menghubungi berkali-kali agar permintaan dapat dipenuhi.

Proses permintaan barang dan pengendalian stok barang saat ini akan dibuatkan sebuah aplikasi sistem informasi inventori. Pada aplikasi ini akan mempermudah proses permintaan barang dari puskesmas ke DKK Padang, pengendalian stok barang APD yang dapat di update secara real time, waktu yang dibutuhkan relatif singkat dan cepat. Berikut dijelaskan alur pengendalaian stok dalam sebuah sistem informasi inventori yang akan diusulkan dengan menggunakan Business Process Modelling Notation (BPMN):

\section{a. Model Bisnis Permintaan Barang}

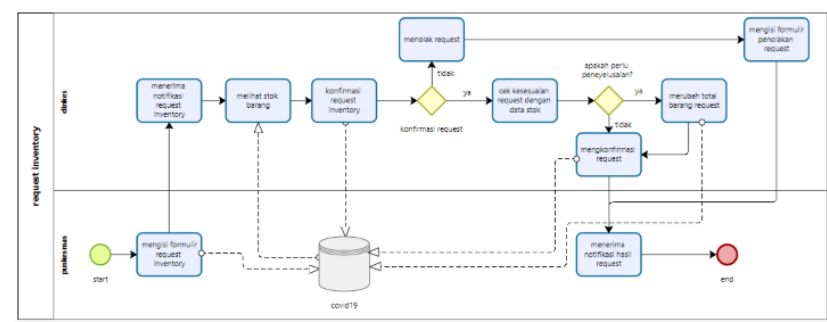

Gambar 5. Model bisnis permintaan barang yang diusulkan

Pada gambar 5 dapat dijelaskan tahapan model bisnis permintaan barang yang diusulkan sebagai berikut: 1) Puskesmas mengisi form permintaan barang pada aplikasi;
2) DKK Padang menerima form permintaan barang dari puskesmas; 3) DKK Padang melakukan konformasi terhadap permintaan barang dari puskesmas yang terlebih dahulu melihat apakah stok barang tersebut terpenuhi atau tidak; 4) Konfirmasi permintaan barang dapat berupa diterima atau ditolak. Jika ditolak, maka DKK Padang harus memberi informasi atau alasan kenapa permintaan barang ditolak; 5) Jika permintaan barang diterima, maka DKK Padang dapat melakukan dua proses yaitu: mengubah jumlah permintaan barang atau langsung menerima permintaan tanpa harus mengubah jumlah barang; 6) Proses selesai dan puskesmas akan menerima notifikasi terhadap permintaan barang.

b. Model Bisnis Pengendalian Stok Barang

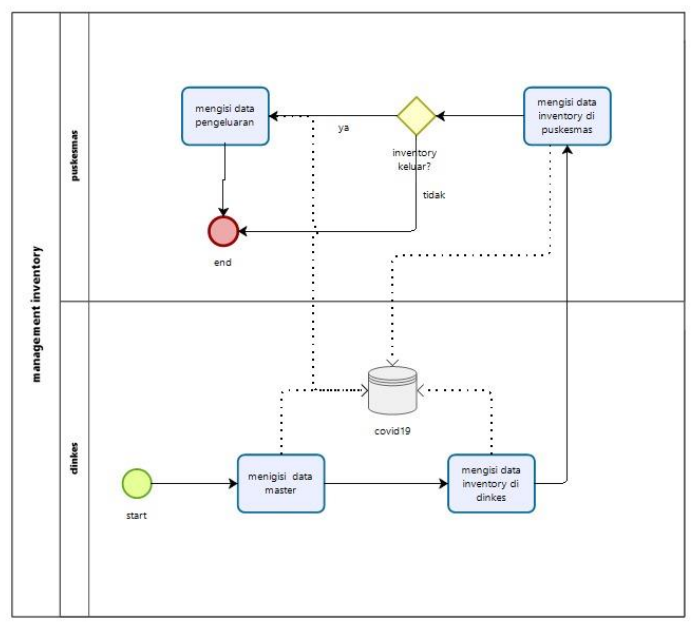

Gambar 6. Model bisnis pengendalian stok barang yang diusulkan

Pada gambar 6 dapat dijelaskan tahapan model bisnis pengendalian stok barang yang diusulkan sebagai berikut: 1) DKK Padang dapat melakukan pengisian data barang yang masuk ke DKK Padang dan juga dapat melakukan pengisian barang masuk di puskesmas; 2) Puskemas dapat melakukan pengisian data barang yang masuk ke puskesmas dan juga barang keluar; 3) Proses pengurangan barang yang ada di DKK Padang terjadi apabila ada permintaan barang dari puskesmas yang kemudian disetujui oleh DKK Padang; 4) Jika terjadi permintaan barang dari puskesmas ke DKK Padang, maka secara otomatis stok barang yang ada pada puskesmas akan bertambah.

3) Use Case Diagram Aplikasi: Hubungan antara komponen fungsional dan aktor sistem digambarkan menggunakan use case diagram. Gambar 7 menggambarkan use case diagram yang menjelaskan peran klien, administrator, dan pemilik [28]. Use case diagram untuk sistem informasi inventori APD DKK Padang berbasis web, seperti yang ditunjukkan di bawah ini: 


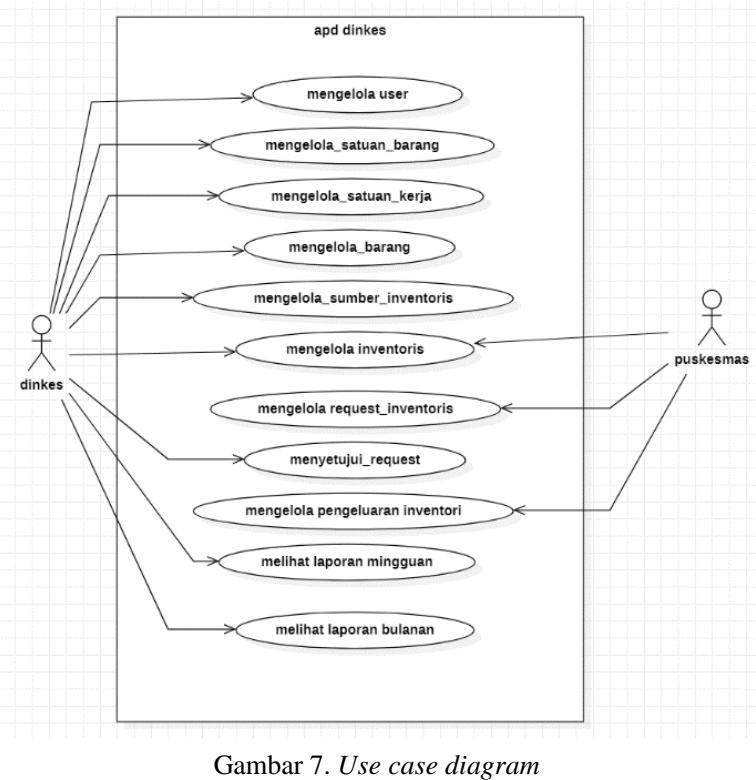

Menurut use case diagram di atas, ada dua aktor yaitu: Dinkes dan Puskesmas. Setiap aktor harus login terlebih dahulu untuk masuk ke aplikasi. Ada 11 fungsi dalam aplikasi ini yang terkait dengan fungsi masing-masing aktor. Aktor Dinkes memiliki 9 fungsional, yaitu: mengelola user, mengelola satuan barang, mengelola satuan kerja, mengelola barang, mengelola sumber inventoris, mengelola inventoris, menyetujui permintaan, melihat laporan mingguan, dan melihat laporan bulanan. Sedangkan aktor Puskesmas memiliki 3 fungsional, yaitu: mengelola inventoris, mengelola permintaan barang, dan mengelola pengeluaran barang.

\section{B. Desain sistem}

Perancangan basis data dan arsitektur antarmuka aplikasi termasuk dalam perancangan sistem ini (antarmuka pengguna).

1) Perancangan Database: Langkah pertama dalam perancangan basis data adalah membuat struktur basis data berdasarkan entitas yang digunakan dan hubungannya dengan entitas lain.. Entitas dan hubungan antara entitas digambarkan dengan ERD (Entity Relationship Diagram). Berikut rancangan ERD pada aplikasi yang di bangun:

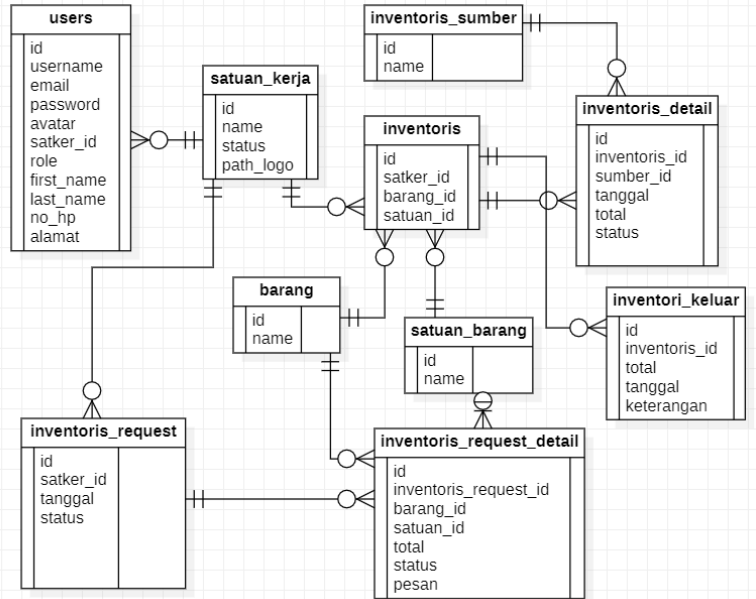

Gambar 8. Rancangan ERD

2) Perancangan Interface: Antarmuka berfungsi sebagai saluran untuk komunikasi antara pengguna dan sistem. Antarmuka sistem dapat menerima dan memberikan informasi kepada pengguna untuk membantu memandu pengguna menelusuri jalan pemecahan masalah hingga solusi ditemukan. Berikut ini adalah beberapa tangkapan layar dari antarmuka pengguna aplikasi.:

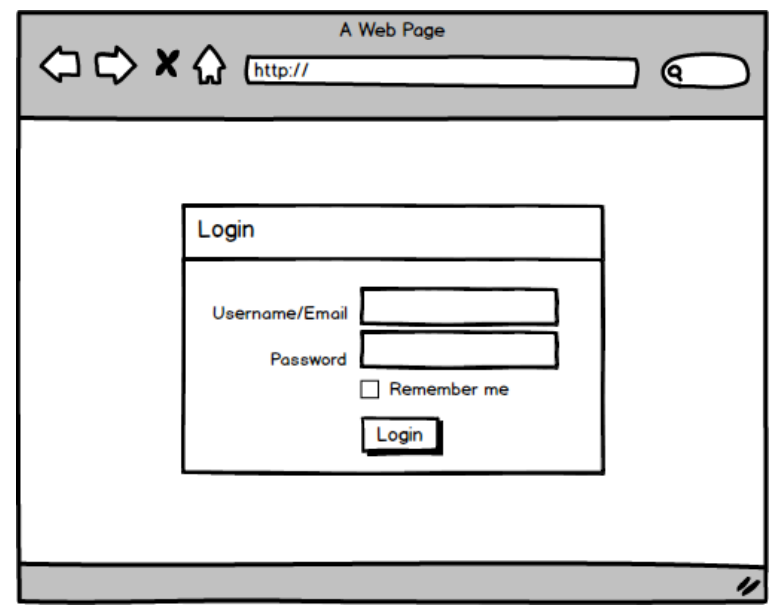

Gambar 9. Rancangan user interface halaman login

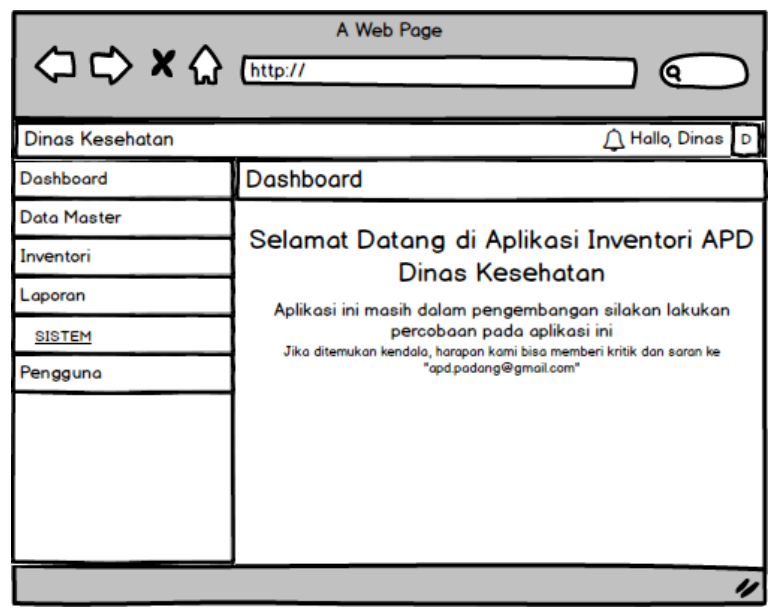

Gambar 10. Rancangan user interface halaman dashboard 


\section{Implementasi Sistem}

Kehadiran sistem informasi memungkinkan instansi untuk memastikan kualitas informasi yang disajikan dan mengambil keputusan berdasarkan informasi tersebut [29]. Perancangan aplikasi sistem informasi inventori dan model bisnis DKK Padang berfungsi sebagai sistem yang mengelola dan menyajikan data dan informasi terkait persediaan barang APD DKK Padang dan permintaan barang dari puskesmas. Ada dua aktor dalam sistem ini, serta sebelas aktor fungsional yang dapat dijalankan. Fungsi ini merepresentasikan tugas setiap pengguna dan diharapkan dapat meningkatkan efisiensi dan efektivitas proses sistem.

Aplikasi ini dibangun dengan bahasa pemrograman PHP (Pearl Hypertext Preprocessor) dan framework Laravel. Kerangka kerja Laravel versi 5.3, serta server web Apache XAMPP versi 3.2.2, digunakan. Server web mengeksekusi bahasa pemrograman PHP di browser dan memproses data database. Database MySQL digunakan sebagai tempat penyimpanan data.

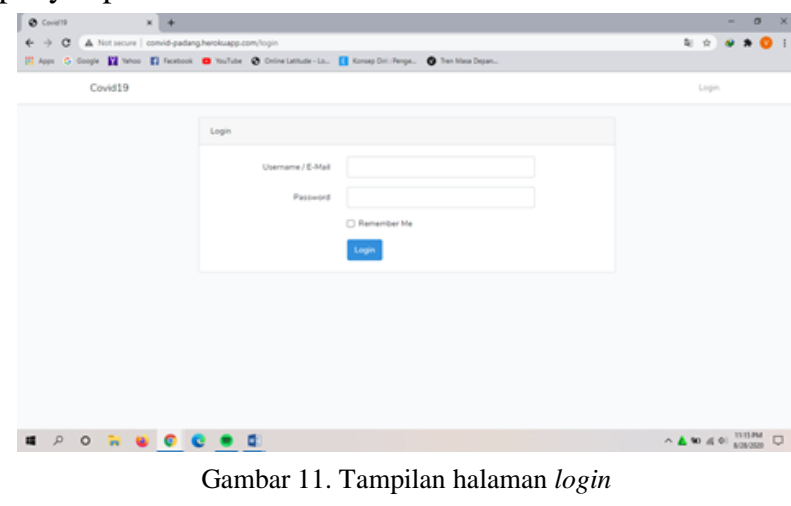

Sesuai Gambar 11, Untuk masuk ke sistem, pengguna harus login terlebih dahulu dengan memasukkan username dan password yang telah disimpan dalam database kemudian mengklik tombol "login". Jika user telah berhasil login maka sistem akan menampilkan halaman utama aplikasi.

Halaman user DKK Padang dapat diakses setelah admin dari DKK Padang melakukan login. User DKK Padang dapat mengelola data pengguna puskesmas, data master berupa data item APD, Satuan barang APD, dan Sumber barang APD, kemudian data inventori. Selain itu user DKK Padang dapat mengelola permintaan barang dari user pusekesmas, serta dapat melihat laporan berupa laporan mingguan inventori. Gambar 12 menggambarkan tampilan halaman pengguna DKK Padang.

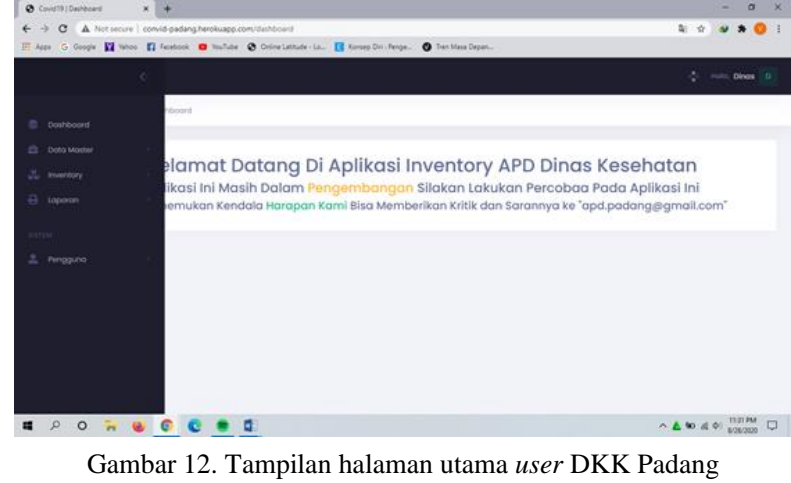

Berdasarkan gambar 12, halaman user DKK Padang memiliki lima menu utama, sembilan submenu, dan dua submenu dari submenu inventori, yang dijelaskan di bawah ini: 1) menu Dashboard, yang menampilkan informasi bahwa user telah berhasil login dan berada sebagai user DKK Padang serta memberikan informasi untuk dapat menghubungi alamat email yang tertera pada aplikasi jika terjadi sebuah kendala teknis pada aplikasi ini; 2) menu Data Master, terdapat tiga submenu, yaitu; Barang, Satuan Barang, dan Sumber. Submenu ini berfungsi untuk memasukkan data barang APD, input data barang APD ini harus sesuai dengan barang yang ada pada gudang di DKK Padang; 3) menu Inventori, yang terdiri dari dua submenu yaitu Request Inventori dan Inventori. Pada submenu Request Inventori, user dapat mengelola permintaan barang dari user puskesmas dan pada submenu Inventori, user dapat menampilkan persediaan barang yang ada di DKK Padang dan Puskemas; 4) menu Laporan, dimana terdapat dua submenu, yaitu: Laporan Mingguan dan Laporan Keluar. Masing-masing submenu menampilkan informasi berupa laporan mingguan dan keluar dari inventori barang APD, dan 5) menu Pengguna, yang menampilkan dua submenu, yaitu: Satuan Kerja dan Pengguna. Pengguna DKK Padang memiliki kemampuan untuk mengelola setiap data pengguna, seperti menambah, memperbarui, dan menghapus data pengguna Puskemas.

Halaman user puskesmas dapat diakses setelah admin dari masing-masing puskesmas melakukan login. User puskesmas memiliki wewenang dalam mengelola inventor dan permintaan barang (request inventory). Tampilan halaman user puskesmas ini dapat dilihat pada gambar 13 .

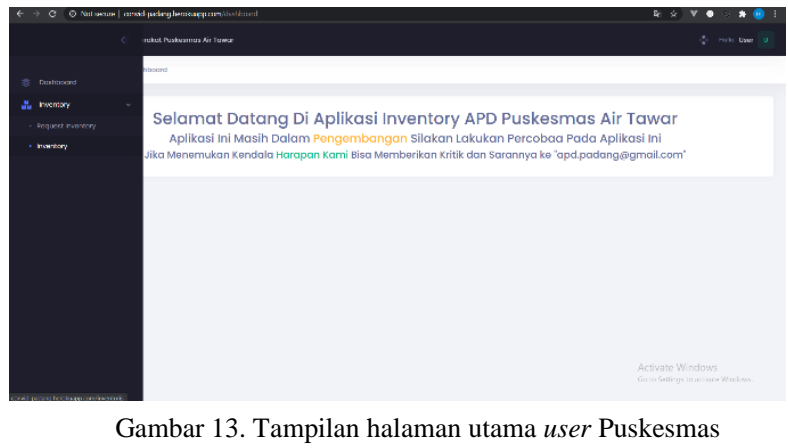

Berdasarkan gambar 13, halaman pengguna puskesmas memiliki dua menu utama dan dua submenu, yang dijelaskan di bawah ini.: 1) menu Dashboard, yang 
menampilkan infomrasi bahwa user telah berhasil login dan berada sebagai user Puskesmas serta memberikan informasi untuk dapat menghubungi alamat email yang tertera pada aplikasi jika terjadi sebuah kendala teknis pada aplikasi ini, dan 2) menu Inventory, yang terdiri dari dua submenu yaitu Request Inventory dan Inventory. Pada submenu Request Inventory, user dapat mengelola permintaan barang ke user DKK Padang dan pada submenu Inventory, user dapat menampilkan persediaan barang yang ada di Puskemas tersebut. Sistem informasi inventori ini diharapkan pada akhirnya dapat membantu dalam perhitungan dan pengecekan barang keluar, barang masuk, dan stok barang di gudang, serta memprediksi persediaan barang dalam beberapa bulan mendatang [30].

\section{Pengujian Sistem}

Penekanan pengujian aplikasi sistem yang dibangun dengan data uji berdasarkan data yang diujikan pada aplikasi.

TABEL II

FOKUS PENGUJIAN

\begin{tabular}{|c|l|l|}
\hline No & \multicolumn{1}{|c|}{ Item yang Diuji } & Proses yang Diuji \\
\hline 1 & Mengelola pengguna & Tambah \\
\hline 2 & Mengelola data barang & Tambah, edit, hapus \\
\hline 3 & Mengelola data satuan barang & Tambah, edit, hapus \\
\hline 4 & $\begin{array}{l}\text { Mengelola data sumber } \\
\text { barang }\end{array}$ & Tambah, edit, hapus \\
\hline 5 & Mengelola request inventory & Lihat, edit, hapus \\
\hline 6 & Mengelola inventory & $\begin{array}{l}\text { Lihat, tambah, edit, } \\
\text { hapus }\end{array}$ \\
\hline 7 & $\begin{array}{l}\text { Melihat dan mencetak } \\
\text { laporan mingguan }\end{array}$ & Lihat, cetak \\
\hline 8 & $\begin{array}{l}\text { Melihat dan mencetak } \\
\text { laporan keluar }\end{array}$ & Lihat, cetak \\
\hline
\end{tabular}

Pengujian dilakukan pada fokus pengujian yang telah ditentukan. Pengujian dilakukan dengan cara black box testing, yaitu berdasarkan fitur sistem, dengan perhatian khusus diberikan pada input dan output sistem. Berikut tabel pengujian sistem yang telah dilaksanakan.

TABEL III

PENGUJIAN SISTEM

\begin{tabular}{|c|c|c|c|c|}
\hline No & $\begin{array}{c}\text { Item yang } \\
\text { di Uji }\end{array}$ & $\begin{array}{c}\text { Data } \\
\text { Masukan }\end{array}$ & Pengamatan & Hasil \\
\hline 1 & $\begin{array}{l}\text { Mengelola } \\
\text { pengguna }\end{array}$ & $\begin{array}{l}\text { Semua data } \\
\text { yang } \\
\text { dibutuhkan pad } \\
\text { form "Buat } \\
\text { Pengguna" }\end{array}$ & $\begin{array}{l}\text { Data } \\
\text { tersimpan, } \\
\text { sistem } \\
\text { menampilkan } \\
\text { halaman daftar } \\
\text { pengguna, dan } \\
\text { notifikasi data } \\
\text { tersimpan }\end{array}$ & sesuai \\
\hline 2 & $\begin{array}{l}\text { Mengelola } \\
\text { data barang }\end{array}$ & $\begin{array}{l}\text { Semua data } \\
\text { yang } \\
\text { dibutuhkan } \\
\text { pada form } \\
\text { "Barang" }\end{array}$ & $\begin{array}{l}\text { Data } \\
\text { tersimpan, } \\
\text { sistem } \\
\text { menampilkan } \\
\text { halaman daftar } \\
\text { barang, dan } \\
\text { notifikasi data } \\
\text { tersimpan }\end{array}$ & Sesuai \\
\hline 3 & $\begin{array}{l}\text { Mengelola } \\
\text { data satuan } \\
\text { barang }\end{array}$ & $\begin{array}{l}\text { Semua data } \\
\text { yang } \\
\text { dibutuhkan }\end{array}$ & $\begin{array}{l}\text { Data } \\
\text { tersimpan, } \\
\text { sistem }\end{array}$ & Sesuai \\
\hline
\end{tabular}

\begin{tabular}{|c|c|c|c|c|}
\hline No & $\begin{array}{c}\text { Item yang } \\
\text { di Uji }\end{array}$ & $\begin{array}{c}\text { Data } \\
\text { Masukan }\end{array}$ & Pengamatan & Hasil \\
\hline & & $\begin{array}{l}\text { pada form } \\
\text { "Satuan } \\
\text { Barang" }\end{array}$ & $\begin{array}{l}\text { menampilkan } \\
\text { halaman daftar } \\
\text { satuan barang, } \\
\text { dan notifikasi } \\
\text { data tersimpan }\end{array}$ & \\
\hline 4 & $\begin{array}{l}\text { Mengelola } \\
\text { data sumber } \\
\text { barang }\end{array}$ & $\begin{array}{l}\text { Semua data } \\
\text { yang } \\
\text { dibutuhkan } \\
\text { pada form } \\
\text { "Sumber } \\
\text { Barang" }\end{array}$ & $\begin{array}{l}\text { Data } \\
\text { tersimpan, } \\
\text { sistem } \\
\text { menampilkan } \\
\text { halaman daftar } \\
\text { sumber } \\
\text { barang, dan } \\
\text { notifikasi data } \\
\text { tersimpan }\end{array}$ & Sesuai \\
\hline 5 & $\begin{array}{l}\text { Mengelola } \\
\text { request } \\
\text { inventory }\end{array}$ & $\begin{array}{l}\text { User klik } \\
\text { tombol } \\
\text { terima/tolak }\end{array}$ & $\begin{array}{l}\text { Proses } \\
\text { berhasil, } \\
\text { sistem } \\
\text { menampilkan } \\
\text { halaman detail } \\
\text { request } \\
\text { inventori, dan } \\
\text { terdapat } \\
\text { notifikasi } \\
\end{array}$ & Sesuai \\
\hline 6 & $\begin{array}{l}\text { Mengelola } \\
\text { inventory }\end{array}$ & $\begin{array}{l}\text { Semua data } \\
\text { yang } \\
\text { dibutuhkan } \\
\text { pada form } \\
\text { "Inventori" }\end{array}$ & $\begin{array}{l}\text { Data } \\
\text { tersimpan, } \\
\text { sistem } \\
\text { menampilkan } \\
\text { halaman daftar } \\
\text { inventori, dan } \\
\text { notifikasi data } \\
\text { tersimpan }\end{array}$ & Sesuai \\
\hline 7 & $\begin{array}{l}\text { Melihat dan } \\
\text { mencetak } \\
\text { laporan } \\
\text { mingguan }\end{array}$ & $\begin{array}{l}\text { Tanggal awal } \\
\text { dan tanggal } \\
\text { akhir dari } \\
\text { laporan dan } \\
\text { user klik } \\
\text { tombo cetak } \\
\end{array}$ & $\begin{array}{l}\text { Muncul } \\
\text { laporan } \\
\text { mingguan } \\
\text { berdasarkan } \\
\text { rentang waktu } \\
\text { yang dipilih }\end{array}$ & Sesuai \\
\hline 8 & $\begin{array}{l}\text { Melihat dan } \\
\text { mencetak } \\
\text { laporan } \\
\text { keluar }\end{array}$ & $\begin{array}{l}\text { Tanggal awal } \\
\text { dan tanggal } \\
\text { akhir dari } \\
\text { laporan dan } \\
\text { user klik } \\
\text { tombo cetak }\end{array}$ & $\begin{array}{l}\text { Muncul } \\
\text { laporan keluar } \\
\text { berdasarkan } \\
\text { rentang waktu } \\
\text { yang dipilih }\end{array}$ & Sesuai \\
\hline
\end{tabular}

Tahap pengujian dilakukan pada aplikasi yang dibangun dengan tujuan memfokuskan pada ketersediaan dan kesesuaian fungsional dari sistem yang diuji secara manual. Setelah dilakukan pengujian, didapatkan hasil yang sesuai dengan desain dan keluaran sistem. Selain itu, tidak ada kegagalan dalam salah satu proses atau fungsi selama pengujian.. Dengan demikian dapat disimpulkan bahwa perancangan aplikasi sistem informasi inventori APD DKK Padang telah beroperasi sesuai dengan fungsi yang dimaksudkan.

Agar sistem yang telah dibuat dapat berjalan secara optimal, hendaknya dilakukan maintenance secara berkala untuk menghindari kerusakan sistem dan kehilangan data yang nantinya akan merugikan instansi [31].

\section{E. Evaluasi Sistem}

Evaluasi sistem ini dilakukan dengan menyebarkan kuesioner terhadap seluruh responden yang berjumlah 25 orang dengan memberikan pertanyaan dari indikatorindikator yang telah dibuat. Berikut adalah tabel kuesioner pada peneltian ini. 
TABEL IV

DAFTAR PERTANYAAN KUESIONER

\begin{tabular}{|c|c|c|c|c|c|c|}
\hline No & Pertanyaan & STS & TS & $\mathbf{R G}$ & $\mathbf{S}$ & SS \\
\hline \multicolumn{7}{|c|}{ a. $\quad$ Performance } \\
\hline $1 \mathrm{a}$ & $\begin{array}{l}\text { Secara umum, aplikasi } \\
\text { menghasilkan output yang } \\
\text { banyak }\end{array}$ & & & & & \\
\hline $2 \mathrm{a}$ & $\begin{array}{l}\text { Aplikasi melakukan proses } \\
\text { kerja yang bertahap dan } \\
\text { cepat }\end{array}$ & & & & & \\
\hline $3 a$ & $\begin{array}{l}\text { Fungsi kerja aplikasi } \\
\text { berjalan sesuai standar } \\
\text { yang ditetapkan }\end{array}$ & & & & & \\
\hline $4 \mathrm{a}$ & $\begin{array}{l}\text { Antarmuka aplikasi mudah } \\
\text { dipahami oleh pengguna }\end{array}$ & & & & & \\
\hline $5 \mathrm{a}$ & $\begin{array}{l}\text { Dokumentasi dan design } \\
\text { yang terdapat pada aplikasi } \\
\text { sudah lengkap }\end{array}$ & & & & & \\
\hline $6 a$ & $\begin{array}{l}\text { Terdapat kesalahan yang } \\
\text { banyak pada aplikasi }\end{array}$ & & & & & \\
\hline \multicolumn{7}{|c|}{ b. Information/Data } \\
\hline $1 \mathrm{~b}$ & $\begin{array}{l}\text { Aplikasi melakukan proses } \\
\text { perhitungan dengan teliti }\end{array}$ & & & & & \\
\hline $2 b$ & $\begin{array}{l}\text { Informasi yang diperoleh } \\
\text { pada aplikasi sesuai } \\
\text { dengan kebutuhan } \\
\text { pengguna }\end{array}$ & & & & & \\
\hline $3 b$ & $\begin{array}{l}\text { Informasi yang } \\
\text { ditampilkan pada aplikasi } \\
\text { sesuai dengan kebutuhan } \\
\text { pengguna }\end{array}$ & & & & & \\
\hline $4 \mathrm{~b}$ & $\begin{array}{l}\text { Pengguna mudah dalam } \\
\text { mengakses data pada } \\
\text { aplikasi }\end{array}$ & & & & & \\
\hline \multicolumn{7}{|c|}{ c. Economic } \\
\hline $1 \mathrm{c}$ & $\begin{array}{l}\text { Banyak program yang } \\
\text { dapat digunakan kembali } \\
\text { pada aplikasi lain }\end{array}$ & & & & & \\
\hline $2 \mathrm{c}$ & $\begin{array}{l}\text { Dalam menjalankan } \\
\text { aplikasi ini memerlukan } \\
\text { banyak pengguna }\end{array}$ & & & & & \\
\hline \multicolumn{7}{|c|}{ d. Control/Security } \\
\hline $1 \mathrm{~d}$ & $\begin{array}{l}\text { Aplikasi memberlakukan } \\
\text { pembatasan yang sesuai } \\
\text { terhadap pengguna untuk } \\
\text { program tertentu }\end{array}$ & & & & & \\
\hline $2 \mathrm{~d}$ & $\begin{array}{l}\text { Aplikasi menjamin } \\
\text { keamanan data }\end{array}$ & & & & & \\
\hline \multicolumn{7}{|c|}{ e. Efficiency } \\
\hline $1 \mathrm{e}$ & $\begin{array}{l}\text { Pengguna mudah dalam } \\
\text { mempelari cara } \\
\text { pengoperasian aplikasi }\end{array}$ & & & & & \\
\hline $2 \mathrm{e}$ & $\begin{array}{l}\text { Pengguna mudah dalam } \\
\text { memcari dan membetulkan } \\
\text { kesalahan }\end{array}$ & & & & & \\
\hline \multicolumn{7}{|c|}{ f. $\quad$ Service } \\
\hline $1 \mathrm{f}$ & $\begin{array}{l}\text { Aplikasi teliti dalam } \\
\text { melakukan proses kerja }\end{array}$ & & & & & \\
\hline $2 \mathrm{f}$ & $\begin{array}{l}\text { Aplikasi dapat diandalkan } \\
\text { dalam menyelesaikan } \\
\text { pekerjaan }\end{array}$ & & & & & \\
\hline $3 \mathrm{f}$ & $\begin{array}{l}\text { Pengguna mudah dalam } \\
\text { memahami aplikasi }\end{array}$ & & & & & \\
\hline
\end{tabular}

Kuesioner yang telah diisi oleh masing-masing responden diolah dalam beberapa langkah dibawah ini, yaitu:
1) Uji Validitas: Dalam penelitian ini uji validitas menggunakan signifikasi $5 \%$ dengan responden dalam penelitian ini berjumlah 25 orang.

TABEL V

UJI VALIDITAS

\begin{tabular}{|c|c|c|c|}
\hline $\begin{array}{c}\text { Butir } \\
\text { Pertanyaan }\end{array}$ & r tabel & r hitung & Validitas \\
\hline 1a & 0,396 & 0,635 & Valid \\
\hline 1b & 0,396 & 0,524 & Valid \\
\hline 1c & 0,396 & 0,504 & Valid \\
\hline 1d & 0,396 & 0,615 & Valid \\
\hline 1e & 0,396 & 0,410 & Valid \\
\hline 1f & 0,396 & 0,409 & Valid \\
\hline 2a & 0,396 & 0,423 & Valid \\
\hline 2b & 0,396 & 0,519 & Valid \\
\hline 2c & 0,396 & 0,419 & Valid \\
\hline 2d & 0,396 & 0,432 & Valid \\
\hline 3a & 0,396 & 0,487 & Valid \\
\hline 3b & 0,396 & 0,476 & Valid \\
\hline 4a & 0,396 & 0,516 & Valid \\
\hline $4 b$ & 0,396 & 0,501 & Valid \\
\hline $5 a$ & 0,396 & 0,518 & Valid \\
\hline $5 b$ & 0,396 & 0,628 & Valid \\
\hline 6a & 0,396 & 0,521 & Valid \\
\hline $6 b$ & 0,396 & 0,519 & Valid \\
\hline $6 \mathrm{c}$ & 0,396 & 0,644 & Valid \\
\hline
\end{tabular}

Berdasarkan tebel di atas, data pada kuesioner valid dikarenakan nilai dari $r$ hitung lebih besar daripada $r$ tabel.

2) Uji Reliabilitas: Kuesioner kuesioner dikatakan reliabel apabila nilai cronbach's alpha lebih besar dari $\mathrm{r}$ tabel pada uji reliabilitas. Hasil uji reliabilitas menggunakan SPSS diketahui bahwa nilai Cronbach's alpha adalah 0,515 yang berarti nilai tersebut lebih besar dari pada nilai $r$ tabel, yaitu 0,396. Jadi dapat disimpulkan bahwa angket reliabel.

TABEL VI

RELIABILITY STATISTICS

\begin{tabular}{|r|r|}
\hline $\begin{array}{c}\text { Cronbach's } \\
\text { Alpha }\end{array}$ & \multicolumn{1}{|c|}{$\begin{array}{c}\text { N of } \\
\text { Items }\end{array}$} \\
\hline, 515 & 19 \\
\hline
\end{tabular}

3) Analisis Data: Untuk menganalisa data, metode yang digunakan yaitu dengan menentukan nilai mean (ratarata) dari nilai yang dihasilkan dari kuesioner yang didapatkan dari jawaban masing-masing responden, Langkah selanjutnya adalah menghitung nilai mean pada setiap indikator yang tealah ditetapkan. Adapun rumus mean yang digunakan adalah seperti dibawah ini:

$$
M e=\frac{\sum x i}{N}
$$

Keterangan:

$\mathrm{Me}=$ mean atau rata-rata

$\sum x i=$ jumlah nilai $\mathrm{x}$ ke 1 sampai ke $\mathrm{n}$

$\mathrm{N}=$ jumlah responden

Untuk mendapatkan data dari hasil perhitungan mean tentang evaluasi sistem informasi inventori ini 
menggunakan skala interval. Untuk mendapatkan skala interval, maka digunakan rumus sebagai berikut:

$$
R s=\frac{m-n}{b}
$$

Keterangan:

Rs $=$ rentang skala yang di cari

$\mathrm{m}=$ skor tertinggi pada kuesioner yang digunakan dalam penelitian ini. Rentang skor antara 1-5. 1 angka terendah dan 5 angka tertinggi

$\mathrm{n}=$ angka pengukuran terendah, yaitu 1

$\mathrm{b}=$ angka tpengukuran ertinggi, yaitu 5

Dari rumus diatas, maka didapatkan nilai Rs nya adalah sebesar 0,8 . Oleh karena itu, rentang skala yang didapatkan dari nilai interval sebanyak 0,8 adalah sebagai berikut:

$1,0<x \leq 1,8$ (Sangat Buruk)

$1,8<x \leq 2,6$ (Buruk)

$2,6<x \leq 3,4$ (Cukup Baik)

$3,4<x \leq 4,2$ (Baik)

$4,2<x \leq 5,0$ (Sangat Baik)

Dibawah ini akan dijelaskan mean dari masing-masing indikator evaluasi sistem dengan menggunakan metodologi PIECES ini, dapat dirincikan sebagai berikut:

1) Hasil dan Analisis indikator Performance: Pada indikator Performance terdapat lima pertanyaan yang digunakan dalam menghanalisis kinerja sistem. Hasil analisis ditunjukkan pada tabel di bawah ini:

TABEL VII

NILAI TOTAL SKOR INDIKATOR PERFORMANCE

\begin{tabular}{|c|c|c|c|c|}
\hline $\begin{array}{c}\text { Butir } \\
\text { Pertanyaan }\end{array}$ & Responden & $\begin{array}{c}\text { Jumlah } \\
\text { Skor }\end{array}$ & Mean & Kategori \\
\hline 1a & 25 & 76 & 3,04 & $\begin{array}{c}\text { Cukup } \\
\text { Baik }\end{array}$ \\
\hline 1b & 25 & 91 & 3,64 & Baik \\
\hline 1c & 25 & 101 & 4,04 & Baik \\
\hline 1d & 25 & 88 & 3,52 & Baik \\
\hline 1e & 25 & 86 & 3,44 & Baik \\
\hline 1f & 25 & 94 & 3,76 & Baik \\
\hline Total & $\mathbf{1 5 0}$ & $\mathbf{5 3 6}$ & $\mathbf{3 , 5 7}$ & Baik \\
\hline
\end{tabular}

Berdasarkan analisis yang dilakukan pada indikator performance didapatkan nilai mean sebesar 3,57 dengan kategori Baik.

2) Hasil dan Analisis indikator Information/Data: Pada indikator Information/Data terdapat empat pertanyaan yang digunakan dalam menghanalisis informasi yang disajikan sistem. Hasil analisis ditunjukkan pada tabel di bawah ini:

TABEL VIII

NILAI TOTAL SKOR INDIKATOR INFORMATION/DATA

\begin{tabular}{|c|c|c|c|c|}
\hline $\begin{array}{c}\text { Butir } \\
\text { Pertanyaan }\end{array}$ & Responden & $\begin{array}{c}\text { Jumlah } \\
\text { Skor }\end{array}$ & Mean & Kategori \\
\hline 2a & 25 & 107 & 4,28 & $\begin{array}{c}\text { Sangat } \\
\text { Baik }\end{array}$ \\
\hline 2b & 25 & 93 & 3,72 & Baik \\
\hline 2c & 25 & 104 & 4,16 & Baik \\
\hline 2d & 25 & 93 & 3,72 & Baik \\
\hline Total & $\mathbf{1 0 0}$ & $\mathbf{3 9 7}$ & $\mathbf{3 , 9 7}$ & Baik \\
\hline
\end{tabular}

Berdasarkan analisis yang dilakukan pada indikator information/data didapatkan nilai mean sebesar 3,97 dengan kategori Baik.

3) Hasil dan Analisis indikator Economic: Pada indikator Economic terdapat dua pertanyaan yang digunakan dalam menganalisis ekonomisnya sistem ini. Hasil analisis ditunjukkan pada tabel di bawah ini:

TABEL IX

NILAI TOTAL SKOR INDIKATOR ECONOMIC

\begin{tabular}{|c|c|c|c|c|}
\hline $\begin{array}{c}\text { Butir } \\
\text { Pertanyaan }\end{array}$ & Responden & $\begin{array}{c}\text { Jumlah } \\
\text { Skor }\end{array}$ & Mean & Kategori \\
\hline $3 \mathrm{a}$ & 25 & 72 & 2,88 & $\begin{array}{c}\text { Cukup } \\
\text { Baik }\end{array}$ \\
\hline 3b & 25 & 90 & 3,60 & Baik \\
\hline Total & $\mathbf{5 0}$ & $\mathbf{1 6 2}$ & $\mathbf{3 , 2 4}$ & $\begin{array}{c}\text { Cukup } \\
\text { Baik }\end{array}$ \\
\hline
\end{tabular}

Berdasarkan analisis yang dilakukan pada indikator economic didapatkan nilai mean sebesar 3,24 dengan kategori Cukup Baik.

4) Hasil dan Analisis indikator Control/Security: Pada indikator Control/Security terdapat dua pertanyaan yang digunakan dalam menganalisis pengendalian dan keamanan sistem. Hasil analisis ditunjukkan pada tabel di bawah ini:

TABEL X

NILAI TOTAL SKOR INDIKATOR CONTROL/SECURITY

\begin{tabular}{|c|c|c|c|c|}
\hline $\begin{array}{c}\text { Butir } \\
\text { Pertanyaan }\end{array}$ & Responden & $\begin{array}{c}\text { Jumlah } \\
\text { Skor }\end{array}$ & Mean & Kategori \\
\hline $4 \mathrm{a}$ & 25 & 86 & 3,44 & Baik \\
\hline 4b & 25 & 95 & 3,80 & Baik \\
\hline Total & $\mathbf{5 0}$ & $\mathbf{1 8 1}$ & $\mathbf{3 , 6 2}$ & Baik \\
\hline
\end{tabular}

Berdasarkan analisis yang dilakukan pada indikator control/service didapatkan nilai mean sebesar 3,62 dengan kategori Baik.

5) Hasil dan Analisis indikator Efficiency: Pada indikator Efficiency terdapat dua pertanyaan yang digunakan dalam menganalisis kepraktisan sistem ini. Hasil analisis ditunjukkan pada tabel di bawah ini:

TABEL XI

NILAI TOTAL SKOR INDIKATOR EFFICIENCY

\begin{tabular}{|c|c|c|c|c|}
\hline $\begin{array}{c}\text { Butir } \\
\text { Pertanyaan }\end{array}$ & Responden & $\begin{array}{c}\text { Jumlah } \\
\text { Skor }\end{array}$ & Mean & Kategori \\
\hline $5 \mathrm{a}$ & 25 & 96 & 3,84 & Baik \\
\hline 5b & 25 & 88 & 3,52 & Baik \\
\hline Total & $\mathbf{5 0}$ & $\mathbf{1 8 4}$ & $\mathbf{3 , 6 8}$ & Baik \\
\hline
\end{tabular}

Berdasarkan analisis yang dilakukan pada indikator efficiency didapatkan nilai mean sebesar 3,68 dengan kategori Baik.

6) Hasil dan Analisis indikator Service: Pada indikator Service terdapat tiga pertanyaan yang digunakan dalam menganalisis fasilitas dari sistem. Hasil analisis ditunjukkan pada tabel di bawah ini: 
TABEL XII

NILAI TOTAL SKOR INDIKATOR SERVICE

\begin{tabular}{|c|c|c|c|c|}
\hline $\begin{array}{c}\text { Butir } \\
\text { Pertanyaan }\end{array}$ & Responden & $\begin{array}{c}\text { Jumlah } \\
\text { Skor }\end{array}$ & Mean & Kategori \\
\hline 6a & 25 & 107 & 4,28 & $\begin{array}{c}\text { Sangat } \\
\text { Baik }\end{array}$ \\
\hline 6b & 25 & 86 & 3,44 & Baik \\
\hline 6c & 25 & 99 & 3,96 & Baik \\
\hline Total & $\mathbf{7 5}$ & $\mathbf{2 9 2}$ & $\mathbf{3 , 8 9}$ & Baik \\
\hline
\end{tabular}

Berdasarkan analisis yang dilakukan pada indikator service didapatkan nilai mean sebesar 3,89 dengan kategori Baik.

7) Hasil dan Analisis PIECES: Bagian ini memperlihatkan hasil Analisa masing-masing indikator untuk mendapatkan hasil evaluasi sistem menggunakan metode PIECES. Hasil analisis ditunjukkan pada tabel di bawah ini:

TABEL XIII

NILAI TOTAL SKOR SELURUH INDIKATOR PIECES

\begin{tabular}{|c|c|c|c|}
\hline $\begin{array}{c}\text { Indikator } \\
\text { ke }\end{array}$ & Indikator & $\begin{array}{c}\text { Mean } \\
\text { Indikator }\end{array}$ & Kategori \\
\hline 1 & Performance & 3,57 & Baik \\
\hline 2 & Information/Data & 3,97 & Baik \\
\hline 3 & Economic & 3,24 & Cukup Baik \\
\hline 4 & Control/Security & 3,62 & Baik \\
\hline 5 & Efficiency & 3,68 & Baik \\
\hline 6 & Service & 3,89 & Baik \\
\hline \multicolumn{2}{|c|}{ Total Mean } & 3,66 & Baik \\
\hline
\end{tabular}

Berdasarkan analisis yang dilakukan pada semua indikator PIECES didapatkan nilai mean sebesar 3,66 dengan kategori Baik. Dan penerapan sistem ini baik dan dapat menyelesaikan permasalahan yang ada pada proses bisnis pada DKK Padang sebelum sistem ini diimplementasikan.

\section{KESIMPULAN}

Metode waterfall berhasil digunakan untuk pengembangan atau merancang aplikasi sistem informasi inventari alat pelindung diri di DKK Padang. Berdasarkan hasil dari setiap tahapan metode waterfall yaitu tahapan analisis, perancangan, pengkodean, dan implementasi, maka dapat disimpulkan bahwa perancangan aplikasi sistem informasi inventari APD di DKK Padang telah berhasil dibangun sesuai dengan kebutuhan. desain sistem sebelumnya, dan aplikasi yang dibangun dapat digunakan di Padang.

Hasil dari evaluasi sistem yang telah dirancang dan diimplementasikan menunjukkan bahwa nilai mean adalah sebesar 3,66 dengan kategori baik yang dapat dirincikan dengan masing-masing domain, yaitu: domain performance dengan nilai mean 3,57 dan kategori baik, information/data dengan nilai mean 3,97 dan kategori baik, economic dengan nilai mean 3,24 dan kategori cukup baik, control/security dengan nilai mean 3,62 dan kategori baik, efficiency dengan nilai mean 3,68 dan kategori baik, service dengan nilai mean 3,89 dan kategori baik.

\section{UCAPAN TERIMA KASIH / ACKNOWLEDGMENT}

Penulis mengucapkan terima kasih ke pada Fakultas Teknologi Informasi, Universitas Andalas yang telah banyak membantu penulis dalam menyelesaikan penelitian ini dan membiayai publikasi artikel ini.

\section{REFERENSI}

[1] I. P. A. Diana, I. P. A. Pratama, and E. F. Thalib, "Designing Inventory Information Systems at UD. Miasa Desktop-Based", International Journal of Application Computer Science and Informatic Engineering (ACSIE) Vol.1, No.1, pp. 21 30, 2019. DOI: https://doi.org/10.33173/acsie.36

[2] Y. Theopilus, T. Yogasara, C. Theresia, and J. R. Octavia, "Analisis Risiko Produk Alat Pelindung Diri (APD) Pencegah Penularan COVID-19 untuk Pekerja Informal di Indonesia”, Jurnal Rekayasa Sistem Industri, Volume 9 No 2 - Juli 2020.

[3] M. I. Firmansyah, F. Rahmanto, and D. Setyawan, "The Preparedness for The Covid-19 Pandemic Management in Indonesia", Jurnal Administrasi Kesehatan Indonesia, Volume 8 No 2 December 2020.

[4] A. A. Siddiqui, "The Role of Personal Protective Equipment (PPE) in Prevention of COVID-19 Novel Corona Virus and Fatalities occur due to Non-availability of the PPE", American Journal of Biomedical Science \& Research, ISSN: 2642-1747, 2020.

[5] R. V. Gomeseria," Personal Protective Equipment (PPE) Planning in The Construction Environment," Journal of Engineering Design \& Construction Studies, September, 2019. DOI 10.17605/OSF.IO/VQ4CK

[6] A. Parush, O. Wacht, R. Gomes, and A. Frenkel, "Human Factor Considerations in Using Personal Protective Equipment in the COVID-19 Pandemic Context: Binational Survey Study, J Med Internet Res Vol. 22, No. 6, 2020

[7] A. Cahyaningsih, "Evaluation of Knowledge and Compliance of Nurses on The Use Personal Protective Equipment (PPE) in Intensive Care Unit (ICU) RSUD Panembahan Senopati Bantul Yogyakarta", JMMR (Jurnal Medicoeticolegal dan Manajemen Rumah Sakit), 6 (3): 187-193, December 2017.

[8] J. R. Susanti, W. A. Putranto, and M. D. Khairansyah, "Analisa Kebutuhan dan Sistem Informasi Manajemen Alat Pelindung Diri (APD) pada Perusahaan Pelayaran" Proceeding 2nd Conference on Safety Engineering and Its Application, Vol. 2, No. 1, ISSN No. 2581-1770, 2018.

[9] A. Anisah, and Kuswaya, "Analisis dan Perancangan Sistem Informasi Pengolahan Data Pengeluaran, Penggunaan Bahan dan Hutang dalam Pelaksanaan Proyek pada Pt Banamba Putratama”, Jurnal SIMETRIS, Vol 8 No 2 November 2017.

[10] A. Fahtoni, and D. Dwi, "Rancang Bangun Sistem Extreme Programming Sebagai Metodologi Pengembangan Sistem", Jurnal PROSISKO Vol.3, No.1, Maret, 2016.

[11] I. B. Nusa, "Quality of audit system information for internal control effectiveness", In International Conference on Business, Economic, Social Science, and Humanities-Economics, Business and Management Track, 198-202. Atlantis Press, 2020.

[12] D. Kurniadi, and A. Mulyani, "ImplementasiPengembangan Student Information Terminal (S-IT) UntukPelayanan Akademik Mahasiswa", Jurnal STT-Garut Vol. 13, No. 2, 2016.

[13] Z. Yu, Xiaodong Wang, Yun Liao, and X. Yao, "The Research and Design of the Materials Inventory Management System Based on The Digital Pipeline, International Conference on Advances in Mechanical Engineering and Industrial Informatics (AMEII), 2015

[14] A. A. Opeyemi, B. Fatoba, and B. O. Abisoye, "Design of a Computerized Inventory Management System for Supermarkets International Journal of Science and Research (IJSR), Volume 2 Issue 9, September 2013.

[15] A. Bari, and Kasmawi," Sistem Informasi Manajemen Inventory Secara Online Menggunakan Framework EasyUI”, Jurnal Inovtek Polbeng-Seri Informatika, Vol. 1, No.1, Juni, 2016.

[16] R.Rosidin, and B.O.Lubis, "Implementasi Program Persediaan Barang pada CV. Ardho Teknik Bekasi”, Jurnal SI STMIK Antar Bangsa, Vol.VI, No.2, Agustus, 2017. 
[17] O. Veza, and M. Ropianto, "Perancangan Sistem Informasi Inventory Data Barang Pada PT. Andalas Berlian Motors", Jurnal Teknik Ibnu Sina (JT-IBSI), Vol. 2, No. 2, Oktober, 2017.

[18] E. F. Ripanti, and H. A. Oramahi, "Rancangan Sistem Informasi Pengelolaan Audit Mutu Internal (AMI) Perguruan Tinggi”, JEPIN, Vol. 7, No. 1, April, 2021.

[19] M. S. Rumetna, E. E. Renny, and T. N. Lina, Designing an Information System for Inventory Forecasting (Case Study: Samsung Partner Plaza, Sorong City)", International Journal of Advances in Data and Information Systems Vol. 1, No. 2, pp. 80 88, October 2020.

[20] E. W. Fridayanthie, and T. Mahdiati, "Rancang Bangun Sistem Informasi Permintaan Atk Berbasis Intranet (Studi Kasus: Kejaksaan Negeri Rangkasbitung)", Jurnal Khatulistiwa Informatika, Vol. IV, No. 2 Desember, 2016.

[21] A. Buchori, P. Setyosari, I. W. Dasna, and S. Ulfa, "Mobile Augmented Reality Media Design with Waterfall Model for Learning Geometry in College", International Journal of Applied Engineering Research ISSN 0973-4562 Volume 12, Number 13, pp. 3773-3780, 2017

[22] J. Yu, "Research Process on Software Development Model", ACMME 2018, IOP Conf. Series: Materials Science and Engineering 394, 2018.

[23] R. H. Kulkarni, P. Padmanabham, and K. K. Baseer, "Critical Review of Extended Waterfall Model", International Journal of Scientific \& Engineering Research, Volume 6, Issue 11, November, 2015.
[24] B. O. Lubis, "Sistem Informasi Penjualan Voucher Belanja Pada PT. Plaza Indonesia Reality Tbk. Jakarta”, Jurnal Informatika, Vol. III, No. 1, April, 2016.

[25] D. Puspitasari, "Sistem Informasi Perpustakaan Sekolah Berbasis Web", Jurnal Pilar Nusa Mandiri Vol.XII, No.2, September, 2016.

[26] B. A. Andrei, A. C. Casu-Pop, S. C. Gheorghe, C. A. Boiangiu, "A Study on Using Waterfall and Agile Methods In Software Project Management", Journal Of Information Systems \& Operations Management, May, 2019

[27] L. D. Bentley, J. L. Whitten, System Analysis and Design for the Global Enterprise, 7th ed., New York: McGrawHill, 2007.

[28] [21]F. E. Nugroho, "Perancangan Sistem Informasi Penjualan Online Studi Kasus Tokoku”, Jurnal SIMETRIS, Vol. 7, No. 2 , November, 2016

[29] G. A. Syafarina, "Perancangan Aplikasi Inventory Barang Materials dan Produk", Technologia" Vol 7, No.1, Januari - Maret, hal. 25-33, 2016.

[30] I. P. Diana, and I. P. Pratama, "Designing Inventory Information Systems at UD. Miasa Desktop-Based", International Journal of Application Computer Science and Informatic Engineering (ACSIE), 1(1), 21-30, 2019. https://doi.org/10.33173/acsie.36.

[31] R.D. Asworowati, "Rancang Bangun Sistem Permintaan Dana Perpanjangan Pajak dan Uji KIR Kendaraan Berbasis Web", JIKB: Jurnal Ilmu Komputer dan Bisnis Vol.XII, No.I, hal.215-225, Mei, 2021 